\title{
Ortaokul Matematik Öğretmenlerinin Örüntüler Hakkındaki Görüssleri
}

\author{
Middle School Mathematics Teachers' Opinions on Patterns
}

\section{Emel TOPBAŞ TAT ${ }^{1}$}

${ }^{1}$ Dr. Öğr. Üyesi, Necmettin Erbakan Üniversitesi, Ereğli Eğitim Fakültesi, Matematik ve Fen Bilimleri Eğitimi Bölümü, etopbastat@erbakan.edu.tr , (D)0000-0002-1487-3027

\begin{tabular}{|c|c|c|c|c|}
\hline \multicolumn{5}{|c|}{ Araştırma makalesi/ Research Article } \\
\hline Geliş: 21.10.2020 & 絭 & Kabul: 13.11.2020 & 素 & Yayın: 31.12.2020 \\
\hline \multicolumn{5}{|c|}{$\begin{array}{l}\text { Atıf/Citation } \\
\text { Topbaş Tat, E. (2020). Ortaokul matematik öğretmenlerinin örüntüler hakkındaki görüşleri. Maarif } \\
\text { Mektepleri Uluslararası Eğitim Bilimleri Dergisi, 4(2),19-31. https://doi.org/10.46762/mamulebd.814118 }\end{array}$} \\
\hline \multicolumn{5}{|c|}{$\begin{array}{l}\text { Topbaş Tat, E. (2020). Middle school mathematics teachers' opinions on patterns. Maarif Mektepleri } \\
\text { International Journal of Educational Sciences, } 4 \text { (2), 19-31. https://doi.org/10.46762/mamulebd.814118 }\end{array}$} \\
\hline
\end{tabular}

Öz

$\mathrm{Bu}$ araştırmanın amacl, ortaokul matematik öğretmenlerinin örüntüler hakkındaki görüşlerini incelemektir. Nitel araştırma yöntemlerinden olgubilim deseninin kullanıldığ araştırmada, "Ortaokul matematik öğretmenlerinin örüntü konusuna yönelik görüşleri nelerdir?" sorusuna cevap aranmıştır. Çalışmaya dört ortaokul matematik öğretmeni katılmıştır. Araştırmaya katılan matematik öğretmenlerinin örüntüler hakkındaki görüşlerini belirlemek amacıyla öğretmenlerle yarı yapılandırılmış görüşmeler yapılmıştır. Görüşmeler sonucu elde edilen veriler içerik analizi yöntemiyle analiz edilmiştir. Analizler sonucunda elde edilen bulgular, ortaokul matematik öğretmenlerinin örüntü konusuna yönelik bakış açılarının genel olarak olumlu olduğunu ancak örüntü konusunun önemini açıklamada yetersiz kaldığını ve örüntü öğretiminde çoğunlukla örüntünün kuralını harfle ifade etmede güçlüklerle karşılaştıklarını göstermiştir.

Anahtar Kelimeler: Ortaokul matematik öğretmeni, örüntü, örüntünün kuralı

\section{Abstract}

The purpose of this research is to examine middle school mathematics teachers' opinions on patterns. In this research phenomenology, one of the qualitative research methods, was used. The answer 
to the question of "What are the middle school mathematics teachers' opinions on patterns?" was sought. Four middle school mathematics teachers participated in the study. Semi-structured interviews were used to determine the teachers' opinions on patterns. The data were analyzed through content analysis method. Results of this study showed that middle school mathematics teachers' opinions on patterns were generally positive, but inadequate in explaining the importance of the patterns and that they have mostly faced difficulties in expressing the rule of the pattern algebraically in pattern teaching.

Keywords: Middle school mathematics teacher, pattern, rule of pattern

\section{Giriş}

Matematiksel düşüncenin önemli bir alt boyutu cebirsel düşünmedir. Van de Walle, Karp ve Bay-Williams'a (2010) göre “cebirsel düşünme veya cebirsel muhakeme, sayılar ve işlemlerle genellemeler yapmayı, bu düşünceleri anlamlı sembol sistemleri kullanarak formalize etmeyi ve örüntü ve fonksiyon kavramlarını incelemeyi içerir" (s. 254). "Cebir ve aslında tüm matematik örüntüleri genelleme ile ilgilidir" (Lee, 1996, s. 103). Çocuklar, örüntülere yönelik olarak öncelikle geometrik örüntülerle karşılaşır. Okul Öncesi Eğitimi Programı'na göre bilişsel gelişime yönelik kazanımlardan biri nesnelerle örüntü oluşturmadır (Milli Eğitim Bakanlı̆̆ı [MEB], 2013a). Matematik Dersi Öğretim Programı'na göre ise öğrenciler ilkokul birinci, ikinci ve üçüncü sınıf seviyelerinde geometrik örüntüler alt öğrenme alanında geometrik örüntüler üzerinde çalışırlar (MEB, 2018). İlkokul seviyesinde geometrik örüntüler alt öğrenme alanında, öğrencilerin belirli bir geometrik örüntüyü deneyimlerle bulmaları, nesneler, geometrik şekiller veya cisimlerden oluşan bir örüntüdeki ilişkiyi belirlemeleri, eksik ögeleri bularak örüntüyü tamamlamaları, bir örüntüdeki ilişkiyi görerek aynı ilişkiye sahip örüntüler oluşturmaları ve kaplama örüntüleri yapabilmeleri hedeflenir. İlkokul ikinci sınıf seviyesinde aralarındaki fark sabit olan sayı örüntülerini tanımaya başlayan öğrencilerin dördüncü sınıf seviyesine geldiğinde belli bir kurala göre artan veya azalan sayı örüntülerini oluşturmaları ve kuralını açıklamaları beklenir. Ortaokul beşinci sınıf seviyesinde kuralı verilen sayı ve şekil örüntülerinin istenen adımlarını oluşturma ele alınmakta, yedinci sınıf seviyesinde ise öğrencilerden sayı örüntülerinin kuralını harfle ifade etmeleri beklenmektedir (MEB, 2018).

Matematiksel örüntüleri sayı ve şekil örüntüleri olarak düşünebilir ve bu örüntüleri; (1) sabit örüntüler, (2) aritmetik genişleyen örüntüler ve (3) geometrik genişleyen örüntüler olarak gruplandırabiliriz (Olkun ve Toluk-Uçar, 2006). Örüntülerle günlük yaşamımızda da karşılaşırız. Örneğin, günlük hayatımızdaki sayıları (telefon numaraları ya da şifreler gibi) hatırlamayı kolaylaştırmak için sıklıkla örüntüleri kullanırız (Posamentier ve Krulik, 1998). Ayrıca tarihi binalarda, kilim desenlerinde hatta kaldırım taşlarında bile örüntüleri görmemiz mümkündür. Örüntülerin içerdiği ilişkileri keşfetmek, bunları genellemek yaşadığımız çevreyi daha iyi algılayabilme becerisi geliştirmenin yanı sıra örüntülerin farklı temsilleri özellikle sembolik temsili cebirin temel kavramlarının oluşmasına büyük katkılar sağlayacaktır (MEB, 2009a). 
Matematik örüntülerin bilimidir. Örüntü aramak, örüntüyü tarif etmeyi, başka durumlara aktarmayı ve genişletmeyi öğrenmek matematik yapmanın ve cebirsel düşünmenin bir parçasıdır (Van de Walle vd., 2010). Dolayısıyla örüntüleri tanıma, oluşturma ve devam ettirme cebire giriş için önemli adımlardır (Hargreaves vd., 1998). Ayrıca "bir matematiksel durumu analiz ederken matematiksel örüntü ve ilişkileri açılama ve kullanma", öğrencilere akıl yürütme becerilerinin kazandırılmasında dikkate alınması gereken göstergeler arasındadır (MEB, 2013b, s. V).

Örüntüler, özellikle cebirsel düşünme üzerindeki etkisine yönelik vurgunun artması ile birçok araştırmanın konusu olmuştur. Alanyazında örüntüler üzerine yapılan araştırmaların birçoğu örüntüleri genellemede kullanılan yaklaşım ve stratejileri belirlemeye yöneliktir (ör. Bishop, 2000; Girit ve Akyüz, 2016; Hargreaves vd., 1998; Rivera ve Becker, 2011; Stacey, 1989; Yeşildere ve Akkoç, 2010, 2011; Zazkis ve Liljedahl, 2002). Örneğin, Yeşildere ve Akkoç (2010) araştırmalarında, öğretmen adaylarının sayı örüntülerinin kuralını bulmayı öğretmede kullandıkları stratejileri ardışık sayılar arasındaki ilişkiyi inceleme, tablo yapma, modelleme yapma, denemeyanılma yöntemini kullanma olarak belirlemiş ve öğretmen adaylarının örüntülerle ilgili güçlüklere sahip olduğunu da gözlemlemişlerdir. Bazı araştırmalar ise örüntüler ile ilgili yeterliliklere odaklanmıştır. Gürbüz ve Durmuş (2009) çalışmalarında ilköğretim matematik öğretmenlerinin dönüşüm geometrisi, geometrik cisimler, örüntü ve süslemeler alt öğrenme alanlarındaki yeterliliklerini incelemiş örüntü ve süslemeler konusunda beklenen yeterlik düzeyinde olmayan öğretmen oranını \%44 olarak belirlemişlerdir. Örüntüler üzerine yapılan bazı çalışmalar ise örüntü temelli öğretimin etkilerini incelemiştir. Örneğin, Palabıyık ve Akkuş İspir (2011) örüntü temelli olan ve örüntü temelli olmayan cebir öğretiminin yedinci sınıf öğrencilerinin cebirsel düşünme becerilerine ve matematiğe karşı tutumlarına olan etkilerini incelemiş ve deney grubunun örüntü temelli öğretim sonucunda kavramsal cebir başarılarını kontrol grubuna göre anlamlı derecede yüksek bulmuşlardır.

Alanyazında örüntüler üzerine yapılan çalışmalar incelendiğinde birçoğunun öğrencilerle (ör. Bishop, 2000; Girit ve Akyüz, 2016; Hargreaves vd., 1998; Palabıyık ve Akkuş İspir, 2011; Rivera ve Becker, 2011; Stacey, 1989) ve öğretmen adayları ile (örn., Yeşildere ve Akkoç, 2010, 2011; Zazkis ve Liljedahl, 2002) yapıldığı ancak öğretmenler ile sınırlı sayıda çalışmalar yapıldığı görülmüştür. Benzer şekilde, örüntüler ile ilgili yapılan çalışmalarda çoğunlukla örüntüleri genellemede kullanılan yaklaşım ve stratejilere odaklanıldığı ve örüntülerin öğrencilerin kavramada güçlük çektikleri konulardan olduğu belirlenmiştir. Öğrencilerin örüntülerle karşılaşması ve örüntüler üzerinde çalışmaları önemlidir. Bununla birlikte, öğretmenlerin örüntü konusuna yaklaşımı, bu konudaki görüş ve deneyimleri örüntü konusunun öğretimini etkileyebilecek önemli bir boyuttur. Öğretmen öğretim programının uygulayıcısı, öğrencinin öğrenme sürecinin yönlendiricisidir. Dolayısıyla, öğretmenin bilgi, beceri ve düşünceleri öğrenme-öğretme sürecinin yönlendirilmesinde ön plana çıkmaktadır. Bu yüzden bu çalı̧mada ortaokul matematik öğretmenlerinin örüntüler hakkındaki görüşlerini belirlemek amaçlanmıştır. Bu amaç doğrultusunda, "Ortaokul matematik 
öğretmenlerinin örüntü konusuna yönelik görüşleri nelerdir?" sorusuna cevap aranmıştır.

\section{Yöntem}

Bu bölümde araştırma modeli, katılımcılar, veri toplama aracı ve verilerin analizi konularında bilgilere yer verilmiştir.

\section{Araştırma Modeli}

Araştırmada nitel araştırma yöntemlerinden olgubilim deseni kullanılmıştır. Olgubilim araştırmalarında bir olguyu daha iyi tanımak ve ayrıntılı bir anlayışa sahip olmak amaçlanmaktadır. Bu doğrultuda, veri analizi ile olguya yönelik yaşantıların ve anlamların ortaya çıkarılması hedeflenir (Yıldırım ve Şimşek, 2006). Bu araştırmada ortaokul matematik öğretmenlerinin örüntüler hakkındaki görüşleri incelenmiştir.

\section{Katılımcilar}

$\mathrm{Bu}$ araştırmada amaçlı örnekleme temel alınmıştır. Araştırmaya iki kadın, iki erkek olmak üzere dört ortaokul matematik öğretmeni katılmıştır. Katılımcılar verilerin toplandığ 1 tarih itibariyle bir ylllık mesleki deneyime sahip ve örüntülere yönelik kazanımların yer aldığı 5 . ve 7 . sınıf seviyelerinde matematik öğretmenliği yapmış ortaokul matematik öğretmenlerinden oluşmaktadır. Bulguların sunumunda öğretmenlerin örüntüler hakkındaki görüşlerinden doğrudan alıntılara yer verilmiştir. Alıntılarda öğretmen isimleri belirtilmemiş, Ö1 Öğretmen 1'i temsil etmek üzere Ö1, Ö2, Ö3 ve Ö4 şeklinde kısaltmalara yer verilmiştir.

\section{Veri Toplama Araci}

$\mathrm{Bu}$ çalışmada veriler yarı yapılandırılmış görüşmeler aracılığıyla toplanmıştır. Alan yazın taraması ışığında görüşme formu taslağı hazırlanmıştır. Sorular ortaokul matematik öğretmenlerinin örüntülere yönelik görüsslerini ortaya koyma amaciyla hazırlanmıştır. Görüşme formu kapsam ve anlaşılırlık açısından alanında uzman iki matematik eğitimcisi tarafından incelenmiştir. Uzman görüşleri ışığında son şekli verilen form 10 soru içermektedir. Katılımcıların izni ile ses kayıt cihazı ile kayıt altına alınan görüşmeler yaklaşık olarak 30 dakika sürmüştür.

\section{Verilerin Analizi}

Bu araştırmada veriler 2019-2020 eğitim ve öğretim yılında toplanmış ve içerik analizi tekniği ile analiz edilmiştir. "İçerik analizinde temel amaç, toplanan verileri açıklayabilecek kavramalara ve ilişkilere ulaşmaktır" (Yıldırım ve Şimşek, 2006, s. 227). Görüşmelerden elde edilen veriler öncelikle yazıya geçirilmiş ve düzenlenmiştir. Daha sonra veriler araştırma amacına uygun bir şekilde kodlanarak analiz edilmiştir. Kodlamaların düzenlenmesiyle ortaokul matematik öğretmenlerinin örüntüler hakkındaki görüşleri üç temel kategori altında analiz edilmiştir. Veriler örüntü konusuna bakış açısı, örüntü öğretiminde karşılaşılan zorluklar ve örüntü öğretiminde 
karşılaşılan zorlukları aşmaya yönelik çözüm yolları temaları altında toplanmıştır. Geçerlik ve güvenirliğin sağlanmasına yönelik olarak uzman incelemesinden yararlanılmış ve ulaşılan sonuçlar teyit edilmiştir.

\section{Bulgular}

Bu bölümde, belirlenen üç tema alt başlıklar altında incelenmiştir. Bulgular öğretmenler ile yapılan yarı yapılandırılmış görüşmelerden doğrudan alıntılar ile desteklenmiştir.

\section{Örüntü Konusuna Bakış Açısı}

Araştırmanın sonuçlarına göre, ortaokul matematik öğretmenlerinin örüntü konusuna yönelik bakış açılarının olumlu olduğu söylenebilir. Bu temaya yönelik kodlar önemli, kolay, zor, zevkli ve eğlenceli ifadelerini içermektedir. Öğretmenler örüntü konusunu önemli bulduklarını belirtmişlerdir. Bu tema altında örüntü konusunun önemine dair "günlük hayatta karşılaşma" ve "diğer konularla ilişkili" kodları elde edilmiştir. Öğretmenler (Ö1, Ö3 ve Ö4) örüntü konusunun öğretimine ilişkin olarak, öğrencilerin günlük hayatta örüntülerle birçok yerde karşılaştığını ve bu yüzden örüntülerin öğretiminin önemli olduğunu ifade etmişlerdir. Örneğin Ö1 ve Ö4 örüntü konusuna bakış açlarını şu şekilde belirtmiştir:

Örüntüler günlük hayatta birçok yerde karşımıza çıktığı için bence önemli bir konu. (Ö1)

Örüntü önemli bir konu en basitinden hayatın içinden. (Ö4)

Öğretmenlerden bir diğeri ise örüntülerin hayatın içinden, günlük yaşamda çok fazla karşıllğı olan bir konu olduğunu ifade etmekle beraber başka konularla ilişkisi açısından da önemli olduğunu belirtmiştir. Ö3 örüntü konusunun önemine dair bakış açısını şu şekilde açıklamıştır:

Örüntü hayatın içinden, ilerisi için diziler ve seriler gibi konular için önemli bir adım aslinda. (Ö3)

Buna karşılık Ö2 örüntü konusunu önemli bulmakla birlikte örüntülerin günlük hayatta öğrencilerin karşısına çıkabilecek bir konu olmadığını bu yüzden de matematikte problemler ve üç boyutlu cisimler kadar önemli olmadığını ifade etmiştir. Ö2 örüntü konusunun önemine dair görüşlerini şu şekilde açıklamaktadır:

Hani belli bir örüntü var, düzen var ama bunu gerçek hayatta nerede kullanacaklar. Mesela problem olduğunda problemi gerçek hayata indirgeyebiliyorsun. Üç boyutlu cisimleri mesela dışarıda bir yerde görebiliyorsun ama örüntüyü dışarıda bir yerde görüyor muyuz düzenli olarak ben onu bilmiyorum. Örüntü önemli bir konu, matematikteki konularm hepsi önemli aslında ama bir problem kadar ya da üç boyutlu cisimler kadar önemli olduğunu düşünmüyorum. (Ö2)

Öğretmenler özellikle 5. sinıf düzeyinde örüntüleri öğretme ve öğrenme açısından kolay bir konu olarak nitelendirirken, 7. sınıf düzeyinde özellikle değişken kullanmada ve genel terimi bulmada zorlanılan bir konu olduğunu ifade etmişlerdir. 
Ayrıca, örüntü konusunun özellikle 5. sınıf düzeyinde öğrenciler tarafından kolay algılanmasının öğrencilerin bu konuyu zevkli ve eğlenceli bulmasıyla sonuçlandığını belirtmişlerdir. Öğretmenlerin bu konudaki görüşlerinden örnekler aşağıda sunulmaktadir:

Örüntü bence öğretmesi zor bir konu değil zevkli bir konu öğrenciler de sevmişti. Fakat genel terimi bulurken formüle dayandiğı için biraz oralarda zorlandım. (Ö1)

Örüntüler zor bir konu değil, örneğin şekillerden yararlanıyoruz. Bir şarkının nakaratında bile bir düzen elde edebiliriz. Günlük yaşamda çok fazla karşılı̆̆ı olan bir konu bence öğrenirken ve öğretirken bu aşamada zor değil. Ama soyuta geçince iş genellemelere varınca işte sıkıntı orada oluyor... Öğrenciler 5. sınıfta örüntülerle çok mutlu oluyor. 5. sını çocuğunun defterine baktığınızda problem kısmı boş mesela ama örüntüleri severek yapmış çizilecek etkinlikleri kesinlikle çizmiş. Öğrencinin kitabı o konuda doluydu mesela. (Ö3)

Örüntü eğlenceli bir konu. Ben mesela örüntü bloklarıla örüntüler yaptım, öğrenciler örüntüler yaptı. Çok eğlendiler... Öğrenciler örüntülerde 7. sımıfta zorlanıyorlar çünkü önyargı var. Değişken kullanmak çocuğa zulüm geliyor. (Ö4)

\section{Örüntü Öğretiminde Karşılaşılan Zorluklar}

Öğretmenler, örüntü konusunun çok zor olmadığını, ancak örüntü öğretiminde yine de bazı sorunlar yaşadıklarını ifade etmişlerdir. Öğrencilerin örüntünün nasıl ilerlediğini keşfetmede çok fazla zorlanmadıklarını, örüntünün yakın elemanlarını belirleyebildiklerini fakat örüntünün uzak adımlarını belirlemede ve örüntünün kuralını harfle ifade etmede güçlükler yaşadıklarını belirtmişlerdir. Öğretmenlerin örüntü öğretiminde karşılaşılan zorluklara yönelik görüşlerinden örnekler aşağıda sunulmaktadır:

(Öğrenci) Örüntünün adımlarını tek tek yazmaya çalışıyor. Genel terime ulaşamıyor. Örüntü bu, adımlar ikişer ikişer artıyor tamam diyor. Ama formülize edip genel terime ulaşamıyor. (Ö3)

(Öğrenci) Örüntünün ilk üç adımını verince 6., 7. adıma kadar ilerletebiliyor. Ama 100. adımını sorunca genel terimi bulması gerektiği için orada biraz sorunları olabiliyor... Öğrenciler örüntüyü sözel olarak ifade edebiliyor. Mesela şekil örüntüsünde üzerine ikişer şekil eklenerek ilerleteceğiz diyebiliyorlar. Sembole gelince sıkıntı oluyor. (Ö1)

Bazı öğrencilerim genel terimi bulamadığı için örüntünün ilk terimlerini bulabildi ama mesela 50. terimi bulamıyorlar. Mesela bir öğrencimde şöyle olmuştu. Genel terimi bulmaların yönlendirmek için sorduğum bir soruda 50. terime kadar tek tek yazmış. Mesela 3, 5, 7 demiştim 50. terimi sormuştum. Örüntünün devamını 50. terime kadar yazmış. (Ö2)

Görüşme yapılan öğretmenler ayrıca öğrencilerin örüntünün genel terimini ifade etmede kullanılan " $\mathrm{n}$ " gösterimini kavramakta zorlandıklarını ve harfli sembolleri 
kullanmaya karşı önyargıları olduğunu bu yüzden örüntünün kuralını sözel olarak ifade edebilirken cebirsel olarak ifade edemediklerini vurgulamışlardır.

(Öğrenciler) Örüntünün genel terimini nasıl bulacaklarını önce anlamıyorlar. Özellikle işin içine " $n$ " girince epey kafaları karışıyor. " $n$ " ne öğretmenim, bir 1 verdik, bir 4 verdik n'ye, niye böyle gibi sorular soruyorlar. (Ö2)

Öğrenciler örüntülerde 7. sınıfta zorlanıyorlar çünkü önyargı var. Değişken kullanmak çocu ğa zulüm geliyor. ... İki katının bir fazlası diyerek söylüyor ama $2 a+1$ veya $2 n+1$ diyemiyor. Harfi kullanamıyor bir türlü. Harfi kullanmakta sıkıntı var. (Ö4)

Ö1 öğrencilerden bazılarının örüntünün ilk terimlerinin verildiği durumlarda örüntüyü devam ettirebildiğini ancak aynı örüntü sözel problem durumunda karşılarına çıktığında zorlandıklarını ifade etmiştir. Ö1 bu konudaki görüşlerini aşağıdaki şekilde açıklamıştır:

Örüntüyü problem olarak verince öğrenciler zorluk çekebiliyor. Ama aynı örüntünün üç adımın verince ilerletebiliyorlar. (Ö1)

Benzer şekilde Ö3 de öğrencinin örüntüye yönelik karşılaştı̆̆1 problem durumuna göre belirli zorluklar yaşayabildiğini belirtmiş ve örüntünün ilk birkaç teriminin verilip doğrudan uzak bir teriminin sorulmasının çoğunlukla sorunun yanıtsız bırakılması ile sonuçlandığını belirtmiştir. Ö3’ün bu konudaki görüşleri şu şekildedir:

Örüntünün birkaç adımını verip örneğin doğrudan 49. adımını sorunca sıkıntı olabiliyor. Soruyu bu şekilde görünce boş bırakma gerçekleşebiliyor. Ama adım adım sorunca genel terime ulaşabiliyor. (Ö3)

Ö3 öğrencilerin şekil örüntülerinden sayı örüntülerine geçişte de zorlandıklarını ifade etmiş ve düşüncelerini aşağıdaki şekilde belirtmiştir:

Çocuğa şekil veriyorsun hemen yapıyor ama sayı ile gösterdiğin zaman farklı bir algı oluşuyor. Daha mesafeli yaklaşıyor. Buda somuttan soyuta geçiş ilkesiyle ilgili olabilir. Çocuk soyuta geçtiği an göremiyor gibi oluyor. Bu sayı, burada bir işlem var gibi bir önyargı oluşuyor... En ufak bir önyargısı olan için bir sonraki adım gerçekten ürkütücü olabiliyor. Çocuk anlıyor aslında ama şekilden kopup sayıla ilişkilendirmek istemiyor. Bunda diretiyor öğrenci. (Ö3)

\section{Örüntü Öğretiminde Karşılaşılan Zorlukları Aşmaya Yönelik Çözüm Yolları}

Görüşmelerde öğretmenler örüntü öğretiminde karşılaştıkları zorlukların üstesinden gelmek için kullandıkları ve önerdikleri yolları açıklamışlardır. Bu tema altında konu tekrarı, günlük hayatla ilişkilendirme, öğrencinin öğrenme çabası, basitten zora doğru ilerleme, somutlaştırma, tablo ile temsil etme, alıştırma sayısını artırma ve örüntü bloklarını kullanma kodları ile ilişkilendirilen görüşler toplanmıştır. Örneğin Ö1, örüntü konusunda karşılaşılan problemleri aşmaya yönelik olarak hataları belirleyerek genel tekrar yaptığını belirtmiş ve örüntülerin ilerleyişine günlük hayattan örnekler verilmesinin zorlukları aşmada yardımcı olacağını ifade etmiştir. Ö1 aynı zamanda 
öğrencinin öğrenme çabasının karşılaşılan zorlukların çözümünde önemli olduğunu vurgulamıştır. Ö1 örüntü öğretiminde karşılaştığı zorlukları aşmaya yönelik uygulamalarını ve önerilerini aşağıdaki şekilde açıklamıştır:

Bu tür zorlukların üstesinden gelebilmek için hatalar tespit edip genel tekrar yapıp üzerinde durduk... Örüntünün ilerleyişine günlük hayattan örnekler verilirse zorluklar aşmada yardımcı olur. Öğrencinin kendi çabası da çok önemli. (Ö1)

Genel terimi bulmaya yönelik sorunları çözmek için Ö2, konuyu basit örnekler üzerinde açıklamalar yaparak ve tekrar ederek anlattığını ve öğrencilerin konuyu daha iyi kavradığını belirtmiştir. Öğretmen " $n$ " in ne olduğunun ve genel terimi ifade etmedeki rolünün kavranmasında basitten zora doğru örnekler çözdüğünü ve açıklamalar yaptı̆̆ını ifade etmiştir.

Örüntünün genel terimini nasıl bulacaklarmı önce anlamıyorlar... Basit örnekler üzerinde tekrar edip açıklayınca daha iyi anlıyorlar. Yani basitten zora doğru açıklayınca sıkıntı ortadan kalktı. Bunun kuralı iki artmasıdır dediler başlangıçta. Ama ben " $n$ "ye yönlendirerek ilerledim ve kuralı açıkladım. Örneğin 1, 3, 5, .. şeklindeki örüntüde kural $2 n$ dediler. Tahtaya kaldırdım n yerine 1 yazdllar ilgisi yok, 2 yazdılar ikinci terimle ilgisi yok. Bunu görmesini sağladım... Ben zorluklar gidermek için terimler arasındaki farka baktırdım. n'nin katsayısı bu, n yerine 1 yazdığııızda 1 . terimi elde etmek için elde ettiğgin katsayılı n'ye ne ekleyip ne çıkaracağımı buldurdum. (Ö2)

Konu anlatımında örüntü bloklarının kullanılması ve örüntüyü tablo ile temsil etmek de öğretmenlerin kullandığg ve önerdiği çözüm yollarındandır.

Basitten zora doğru gidiyoruz. 1. adımı inceliyoruz, 2. adımı inceliyoruz, genele ulaşmaya çalı̧ıyoruz. Tabloda daha iyi görüyorlar ilişkileri. Ben bunları yapıyorum, faydah oluyor... Konuyu anlatırken örüntü blokların kullandığım için çok ilgilerini çekti... Örüntülerin öğretiminde örüntü bloklarının kullanımını önerebilirim. (Ö4)

Örüntülerde yaşanan zorlukları aşmak için Ö3 anlatımını somutlaştırdığını belirtmiş ve alıştırma sayısını artırmayı önermiştir. Örüntülerde genel terim konusunda yaşanan zorluğu aşmada ise basit ve günlük hayattan örneklerle adım adım ilerleyerek öğrencinin genel terime ulaşmasını sağladığını belirtmiştir.

Çocuk direkt sayıdan panik oluyorsa mesela bu sıraya dikkat etmeye çalışıorum. Önce somutlaştırıyorum... Alıştırmaları çoğaltarak çocuğa indirgeyerek bu tür sorunların üstesinden gelinebilir... Öğrenciler bu örüntünün terimleri üçer üçer artıyor diyor ama genel terimi yazamıyor. Burada basit örneklerle, günlük hayattan örneklerle, adım adım ilerleyerek genel terime ulaşmalarını sağlıyorum. (Ö3)

\section{Sonuç ve Tartışma}

Verilerin analizi sonucu elde edilen bulgular çalışmaya katılan bir yıllık mesleki deneyime sahip ortaokul matematik öğretmenlerinin örüntü konusuna bakış açısı, örüntü konusunda yaşanan zorluklar ve çözüm yolları açısından görüşlerini yansitmaktadir. 
Araştırmanın sonuçlarına göre, katılımcılardan iki öğretmen örüntü konusunun öğretimine ilişkin olarak, öğrencilerin günlük hayatta örüntülerle birçok yerde karşılaştığını ve bu yüzden örüntülerin öğretiminin önemli olduğunu ifade etmiştir. Bir öğretmen ise örüntülerin hayatın içinden, günlük yaşamda çok fazla karşllığı olan bir konu olduğunu ifade etmekle beraber başka konularla ilişkisi açısından da önemli olduğunu belirtmiştir. Buna karşılık diğer bir öğretmen örüntü konusunu önemli bulmakla birlikte örüntülerin günlük hayatta öğrencilerin karşısına çıkabilecek bir konu olmadığını bu yüzden de matematikte örneğin problemler ve üç boyutlu cisimler kadar önemli olmadığını ifade etmiştir. Oysa tarihi binalarda, kilim desenlerinde hatta kaldırım taşlarında bile örüntüleri görmemiz mümkündür. Benzer şekilde, Matematik Dersi Öğretim Programı'nda 5. sınıf düzeyinde "şekil örüntülerine tarihî ve kültürel eserlerimizden örnekler (mimari yapılar, halı süslemeleri, kilim vb.) verilmesi" ve 7 . sınıf düzeyinde ise "günlük hayat durumlarında veya şekil örüntülerindeki ilişkileri örüntüye dönüştürerek kuralı bulmaya yönelik çalışmalara da yer verilmesi" önerilmektedir (MEB, 2018, s. 51, 67). Bu açıdan, katılımcı öğretmenin örüntülerin önemi hakkındaki görüşlerinin öğretim programı bilgisine yönelik eksikliklerini de yansıttığı söylenebilir. Örüntü, bir sayı dizisi veya bir şekil dizisi olarak karşımıza çıkabilir. Sayılar ve şekiller arası ilişkileri incelemede örüntü oluşturma, verilen bir örüntünün kuralını bulma, kuralı açıklama ya da örüntüde takip eden ögeleri tahmin etme ve tahminlerin neye dayanılarak yapıldığını açılama gibi etkinlikler akıl yürütme ve iletişim becerilerinin gelişmesinde önemli rol oynar. Ayrıca öğrencilerin sayı ve şekil örüntüleri üzerinde çalışmaları matematiğin örüntüleri inceleyen bir çalışma alanı olduğunu hissetmelerini sağlayacaktır (MEB, 2009b). Benzer şekilde, “örüntü genelleme çocukların cebirsel düşünce gelişiminde özellikle değiş̧ken ve fonksiyon kavramlarının gelişimi için önemli bir unsur olarak kabul edilir" (Lee ve Freiman, 2004, s. 245). Bu doğrultuda, araştırmanın sonuçlarına göre, ortaokul matematik öğretmenlerinin örüntü konusuna yönelik bakış açılarının genel olarak olumlu olduğu ancak örüntü konusunun önemini açıklamada yetersiz kaldığ1 söylenebilir. Bu açıdan öğretmen eğitiminde bu konunun üzerinde duracak çalışmalar yapılması önerilmektedir.

$\mathrm{Bu}$ araştırmanın sonuçlarına göre, ortaokul matematik öğretmenleri özellikle 5. sınıf düzeyinde örüntüleri öğretme ve öğrenme açısından kolay bir konu olarak nitelendirirken, 7. sınıf düzeyinde zorlanılan bir konu olduğunu ifade etmişlerdir. Ayrıca, örüntü konusunun özellikle 5. sınıf düzeyinde öğrenciler tarafından zevkli ve eğlenceli bulunduğunu belirtmişlerdir. Matematik Dersi Öğretim Programı 5.-8. sinıf seviyelerinde örüntü konusu açısından incelendiğinde 5. ve 7. sınıf düzeylerinde örüntülerinin ele alındığı görülmektedir. Beşinci sınıf düzeyinde sayılar ve işlemler öğrenme alanının doğal sayılar alt öğrenme alanında "Kuralı verilen sayı ve şekil örüntülerinin istenen adımlarını oluşturur." kazanımı ele alınmaktadır (MEB, 2018, s. 51). Bu sinıf seviyesinde 7 'den başlayan ve üçer ilave etmek suretiyle oluşan sayı örüntüsünün 6. adımını bulunuz örneğindeki gibi sadece adımlar arasındaki farkı sabit olan örüntülerle sınırlı kalınır. Şekil örüntüleri ile ilgili olarak ise örneğin verilen 
bir şekil örüntüsündeki kare ve üçgen sayılarını sayı örüntüsü olarak belirtme veya istenilen adımdaki kare ve üçgen sayılarını bulmaya yönelik çalışmalar yapılması ve şekil örüntülerine tarihi ve kültürel eserlerimizden örnekler verilmesi önerilmektedir (MEB, 2018). Yedinci sınıf seviyesinde cebir öğrenme alanı ve cebirsel ifadeler alt öğrenme alanında öğrenciler örüntüler ile karşılaşmakta ve "Sayı örüntülerinin kuralını harfle ifade eder, kuralı harfle ifade edilen örüntünün istenilen terimini bulur." kazanımı bu sınıf seviyesinde ele alınmaktadır (MEB, 2018, s. 67). Bu sinıf seviyesinde de adımlar arasındaki farkı sabit olan örüntülerle sınırlı kalınır. Öğretim programı değişken kullanımının önemini ve gerekliliğini vurgulayan, sayı örüntülerinin kuralını bir değişken ile yazmaya yönelik çalışmalar önermektedir. Ayrıca günlük hayat durumlarında veya şekil örüntülerindeki ilişkileri de örüntüye dönüştürerek kuralı belirleme çalışmalarının yapılması gerekliliği vurgulanmıştır (MEB, 2018). Bu doğrultuda, araştırmanın sonuçlarına göre, ortaokul matematik öğretmenlerinin görüşleri doğrultusunda öğrencilerin örüntülerle ilgili olarak 7. sınıf seviyesinde cebir öğrenme alanında ele alınan ve "Sayı örüntülerinin kuralını harfle ifade eder, kuralı harfle ifade edilen örüntünün istenilen terimini bulur." kazanımında daha çok zorlandığı söylenebilir. Bu bulgu öğrencilerin değişken kavramıyla zorlu deneyimler yaşadıklarını belirten birçok araştırmanın bulgularıyla paralellik göstermektedir (ör. Knuth, Alibali, McNeil, Weinberg, ve Stephens, 2005; Macgregor ve Stacey, 1997). Değişken kavramının matematikteki yeri ve önemi düşünüldüğünde öğrencilerin değişken kavramını anlamalarına ve kullanmalarına yönelik uygulamalara derslerde ağırlık verilmesi önerilmektedir.

Mevcut araştırma öğretmenlerin örüntü konusunda yaşanan zorluklar hakkındaki görüşlerini de ortaya çıkarmıştır. Yaşanan zorluklardan ilki örüntünün kuralını harfle ifade etme ile ilgilidir. Genel terimi bulamama, genel terimi ifade etmede kullanılan " $n$ " gösterimini kavrayamama ve harfli sembolleri kullanmaya karşı önyargıların olması belirtilen zorluklardandır. Bu zorluklar dolayısıyla bazı öğrencilerin örüntünün kuralını sözel olarak ifade edebildiği ancak cebirsel olarak ifade edemediği de belirtilmiştir. Benzer şekilde, Zazkis ve Liljedahl (2002) öğretmen adaylarının örüntüleri genellemeleri üzerine yapmış oldukları çalışmalarında öğrencilerin genellemeyi sözlü olarak ifade etme yeteneğinin cebirsel notasyona eşlik etmediğini ve buna bağlı olmadığını bulmuşlardır. Ayrıca, mevcut çalışmanın bulguları matematiksel genellemenin birçok öğrenci için zorlu bir görev olduğunu belirten çalışmaları destekler niteliktedir (ör. Bills, Ainley ve Wilson, 2006; Lee, 1996).

Öğretmenlerin belirttiği bazı zorluklarda ise önyargı kavramı dikkat çekmektedir. Örneğin harfli sembolleri kullanmaya karşı önyargıların olduğu ve bu önyargıların zorluklara neden olabildiği ifade edilmiştir. Ayrıca öğrencilerin şekil örüntülerine olumlu tutum gösterdiği fakat sayı örüntülerine karşı önyarg1 ile yaklaşan öğrencilerinin, şekil örüntülerinden sayı örüntülerine geçişte zorlandığı da belirtilmiştir. Umay (1996) matematiğin zorluğunun yapısının yanında ona karşı geliştirilen önyarg1 ve korkudan da kaynaklanabileceğini belirtmiştir. Bu doğrultuda 
örüntülerle yaşanan zorlukları aşmada öğrencilerin bu ön yargılarını yıkacak bir öğretim planı gerekmektedir.

Çalışmanın sonuçlarına göre, öğrenciler örüntülerle doğrudan bir sayı dizisi ya da geometrik örüntü olarak karşılaştığında zorluk çekmezken eğer örüntü bir problem durumunun içinde sunuluyor ise öğrencinin bunu örüntü olarak ifade edip ilerletmesinde sıkıntılar yaşanabildiği belirtilmiştir. Dolayısıyla, öğretmen görüşleri doğrultusunda, örüntülerle ilgili yaşanan zorluklardan birinin örüntü sunum biçimi ile ilgili olduğu söylenebilir. Bu bulgu örüntü sunum biçimlerine göre öğrencilerin matematiksel örüntüleri algılayışlarının ve performanslarının değiştiğini belirten bazı çalışmaların bulgularını desteklemektedir. Örneğin, Yaman ve Umay (2013) ilköğretim 3, 4, 5, 6 ve 7. sınıf öğrencilerinin örüntü başarı testinde en yüksek puanı tablo biçiminde sunulan örüntü sorularında aldığını ve diğer sunum biçimlerinde de puan sıralamasının şekil, sözel problem ve sayı dizisi biçiminde olduğunu bulmuşlardır. Mevcut araştırmada örüntülerle ilgili sunulan problem durumunun da önemi belirtilmiş ve doğrudan genel terimi ya da örüntünün uzak adımlarını sormanın öğrencinin problemden vazgeçmesi ile sonuçlandığı ifade edilmiştir. Benzer şekilde, Zazkis, Liljedal ve Chernoff (2008) araştırmalarında örnek seçiminin öğrencilerin genellemelerini sağlayan deneyimler oluşturmada etkili olduğunu bulmuşlardır.

Araştırmanın bulguları ortaokul matematik öğretmenlerinin örüntülerde karşılaşılan zorlukların üstesinden gelme yollarını da yansıtmaktadır. Örüntüleri günlük hayatla ilişkilendirme kullanılan çözüm yollarından biridir. Ayrıca öğrencinin öğrenme çabasının karşılaşılan zorlukların çözümünde önemli olduğu vurgulanmıştır. Konu tekrarı yapmak, basitten zora doğru ilerlemek, somutlaştırmayı sağlamak, alıştırma sayısını artırmak, örüntü bloklarının kullanılması ve örüntüyü tablo ile temsil etmek öğretmenlerin kullandığı ve önerdiği çözüm yollarındandır. Alanyazın öğrencilerin matematiksel örüntüleri algılayışlarının ve performanslarının örüntülerin sunum biçimlerinden etkilendiğini (Yaman ve Umay, 2013), güçlü bir cebirsel dil ve düşünce gelişimi için çoklu temsiller arasında anlamlı ilişkiler kurulması gerektiğini (Steele, 2008) ve öğrencilerin genelleme yaklaşımlarını etkilemede sosyal etkileşimin, bilişsel faktörlerin ve problem durumunun yapisının önemini (Lannin, Barker ve Townsend, 2006) vurgulamaktadır. Bu doğrultuda, öğretmen eğitiminde örüntü öğretiminde karşılaşılan zorluklar ve çözüm yolları üzerinde durulması öğretmenlerin etkili bir öğretimde ihtiyaç duyacakları bilgi ve becerileri edinmelerinin sağlanması açısından önemlidir.

\section{Etik Beyan}

“Ortaokul Matematik Öğretmenlerinin Örüntüler Hakkındaki Görüşleri” başlıklı çalışmanın yazım sürecinde bilimsel, etik ve alıntı kurallarına uyulmuş; toplanan veriler üzerinde herhangi bir tahrifat yapılmamış ve bu çalışma herhangi başka bir akademik yayın ortamına değerlendirme için gönderilmemiştir. 


\section{Kaynaklar}

Bills, L., Ainley, J., \& Wilson, K. (2006). Modes of algebraic communication: Moving from spreadsheet to standard notation. For the Learning of Mathematics, 26(1), 36-41.

Bishop, J. (2000). Linear geometric number patterns: Middle school students' strategies. Mathematics Education Research Journal, 12(2), 107-126.

Girit, D. \& Akyüz, D. (2016). Algebraic thinking in middle school students at different grades: Conceptions about generalization of patterns. Necatibey Ĕgitim Fakültesi Elektronik Fen ve Matematik Ĕ̆itimi Dergisi, 10(1), 243-272.

Gürbüz, K. \& Durmuş, S. (2009). İlköğretim matematik öğretmenlerinin dönüşüm geometrisi, geometrik cisimler, örüntü ve süslemeler alt öğrenme alanlarındaki yeterlikleri. Abant İzzet Baysal Üniversitesi Dergisi, 9(1), 1-22.

Hargreaves, M., Shorrocks-Taylor, D., \& Threlfall, J. (1998). Children's strategies with number patterns. Educational Studies, 24(3), 315-331.

Knuth, E. J., Alibali, M. W., McNeil, N. M., Weinberg, A., \& Stephens, A. C. (2005). Middle school students' understanding of core algebraic concepts: Equivalence \& variable. Zentralblatt für Didaktik der Mathematik (International Reviews on Mathematical Education), 37, 68-76.

Lannin, J., Barker, D., \& Townsend, B. (2006). Algebraic generalisation strategies: Factors influencing student strategy selection. Mathematics Education Research Journal, 18(3), 3-28.

Lee, L. (1996). An initiation into algebraic culture through generalization activities. In N. Bednarz, C. Kieran, \& L. Lee (Eds.), Approaches to algebra. Perspectives for research and teaching (pp. 87-106). Dordrecht: Kluwer Academic Publishers.

Lee, L., \& Freiman, V. (2004). Tracking primary students' understanding of patterns. In D. McDougall \& J. Ross (Eds.), Proceedings of the 26th annual conference of the North American Chapter of the International Group for the Psychology of Mathematics Education (PMENA) (Vol. 2, pp. 245-251). Toronto, Canada: PMENA.

MacGregor, M., \& Stacey, K. (1997). Students' understanding of algebraic notation: 11-15. Educational Studies in Mathematics, 33, 1-19.

MEB (2009a). İlköğretim matematik dersi öğretim programı ve kılavuzu: 6-8. sınıflar. Ankara: Talim ve Terbiye Kurulu Başkanlığı.

MEB (2009b). İlköğretim matematik dersi 1-5. sınıflar öğretim programı. Ankara: Talim ve Terbiye Kurulu Başkanlığ1.

MEB (2013a). Okul öncesi eğitimi programı. Ankara: Milli Eğitim Bakanlığı Temel Eğitim Genel Müdürlüğü.

MEB (2013b). Ortaokul matematik dersi (5, 6, 7 ve 8. Sinıflar) öğretim programı. Ankara: Talim ve Terbiye Kurulu Başkanlığı. 
MEB (2018). Matematik dersi öğretim programı (ilkokul ve ortaokul 1, 2, 3, 4, 5, 6, 7 ve 8. sinıflar). Ankara: Talim ve Terbiye Kurulu Başkanlığı.

Olkun, S. \& Toluk-Ucar, Z. (2006). İlköğretimde matematik öğretimine çağdaş yaklaşımlar. Ankara: Ekinoks.

Palabıyık, U. \& Akkuş İspir, O. (2011). Örüntü temelli cebir öğretiminin öğrencilerin cebirsel düşünme becerileri ve matematiğe karşı tutumlarına etkisi. Pamukkale Üniversitesi Ĕ̆itim Fakültesi Dergisi, 30, 111-123.

Posamentier, A. S., \& Krulik, S. (1998). Problem-solving strategies for efficient and elegant solutions. California: Corwin Press.

Rivera, F., \& Becker, J. (2011). Formation of pattern generalization involving linear figural patterns among middle school students: Results of a three-year study. In J. Cai \& E. Knuth (Eds.), Early algebraization: A global dialogue from multiple perspectives (advances in mathematics education) (Vol. 2, pp. 323-366). New York: Springer.

Stacey, K. (1989). Finding and using patterns in linear generalising problems. Educational Studies in Mathematics, 20, 147-164.

Steele, D. (2008). Seventh-grade students' representations for pictorial growth and change problems. ZDM Mathematics Education, 40, 97-110.

Umay, A. (1996). Matematik öğretimi ve ölçülmesi. Hacettepe Üniversitesi Eğitim Fakültesi Dergisi, 12, 145-149.

Van de Walle, J. A., Karp, K. S., \& Bay-Williams, J. M. (2010). Elementary and middle school mathematics: Teaching developmentally (7th ed.). Boston: Allyn \& Bacon.

Yaman, H. \& Umay, A. (2013). İlköğretim öğrencilerinin sunum biçimlerine göre matematiksel örüntüleri algılayışları. Hacettepe Üniversitesi Ĕ̆itim Fakültesi Dergisi, 28(1) , 405416.

Yeşildere, S. \& Akkoç, H. (2010). Matematik öğretmen adaylarının sayı örüntülerine ilişkin pedagojik alan bilgilerinin konuya özel stratejiler bağlamında incelenmesi. Ondokuz Mayıs Üniversitesi Eğitim Fakültesi Dergisi, 29(1), 125-149.

Yeşildere, S. \& Akkoç, H. (2011). Matematik öğretmen adaylarının şekil örüntülerini genelleme süreçleri. Pamukkale Üniversitesi Eğitim Fakültesi Dergisi, 30, 141-153.

Yıldırım, A. \& Şimşek, H. (2006). Sosyal bilimlerde nitel araştırma yöntemleri (6. Baskı). Ankara: Seçkin Yayıncılık.

Zazkis, R., \& Liljedahl, P. (2002). Generalization of patterns: The tension between algebraic thinking and algebraic notation. Educational Studies in Mathematics, 49, 379-402.

Zazkis, R., Liljedahl, P., \& Chernoff, E. J. (2008). The role of examples in forming and refuting generalizations. ZDM Mathematics Education, 40(1), 131-141. 